\title{
TRAINING PROGRAMME TO DEVELOP YOUNG VOLLEYBALLERS' JUMPING ABILITY
}

\author{
Raini Stamm ${ }^{1}$, Meelis Stamm ${ }^{2}$, Natasha Sorgina ${ }^{1}$, Säde Koskel ${ }^{3}$ \\ ${ }^{1}$ University of Tallinn, Institute of Health Sciences and Sports, Tallinn, Estonia \\ ${ }^{2}$ University of Tallinn, Institute of Educational Sciences, Tallinn, Estonia \\ ${ }^{3}$ University of Tartu, Centre for Physical Anthropology, Tartu, Estonia
}

\begin{abstract}
In the current study, the jumping ability development programme created by A. V. Belyayev and L. V. Bulykina was used in training groups of young volleyballers of different sex and age during 54 days.

The sample being trained consisted of two groups. The first group, aged 16-20 years, consisted of 6 girls and 6 boys. The second group, aged 8-13 years, consisted of 4 girls and 6 boys. All of them were beginning volleyballers who had practised for 1-3 years. The control group consisted of 8 boys aged 17-18years. At the beginning of the experiment all of them underwent anthropometric measuring (6 measurements) and tests - height of standing and running vertical jump, height of block jump (standing jump with both arms stretched upwards and speed of motion was assessed by the method of zigzag run [13]. The control group underwent the same studies but did not participate in the jumping ability development programme. The results revealed that in all groups the results of jumping tests and speed tests improved. Linear correlation analysis of anthropometric measurements and tests results showed a significant correlation between body measurements and tests results. The authors recommend to apply this development programme as an aid for coaches.
\end{abstract}

Key words: young volleyballers, jumping ability development programme, anthropometry.

In volleyball physical abilities serve as a basis for technical performance $[2,6,11]$. Particularly great importance has been attached to jumping 
ability, as most elements that bring points to a team - attack, block and serve - are performed from a jump $[5,8,9,10]$.

Considering the above mentioned, coaches are attempting to create increasingly efficient jumping ability development programmes for young volleyballers.

The aim of this study was to apply the jumping ability programme created by A. V. Belyayev and L. V. Bulykina [1] specially for volleyballers in training groups of young volleyballers of different sex and age.

\section{SUBJECTS OF THE STUDY}

The subjects of the study were beginning young volleyballers who had practised volleyball for 1-3 years. The first group consisted of 12 players aged 16-20 years. They were members of the volleyball hobby group of Tallinn Secondary School No. 23, six girls and six boys. The second group consisted of ten children aged 8-13 years. They were the volleyball group of Tallinn Kalev Sports Society - four girls and six boys. In addition, there was a control group that consisted of students of Form 11 at Tallinn Secondary School No. 23 - eight boys aged 17-18 years. They did not attend volleyball training and did not regularly practise any other sport. They only attended physical education classes at school.

\section{METHODS}

An anthropometric study was carried out with the students of the first and the second group and with the control group. Their height, weight, waist circumference, upper and lower leg circumference, and arms spread were measured according to the methodology of Martin [4]. Thereafter all the subjects underwent tests of physical ability which assessed the height of standing and running vertical jump [12] and the height of block jump (standing jump with two arms stretched upwards). In addition, the subjects' speed was assessed by zigzag run known from literature [13].

After testing the first and second group participated in Belyayev and Bulykina's jumping ability training programme. The authors recommend to conduct such a programme during the preparatory period. 
Stage 1. Jumping ability training every day. During each training session jumping exercises 2, 3, 4, 7 are performed. Number of repetitions for each exercise -20 jumps, 2-3 series. Pauses between series and exercises 1-2 minutes.

Stage 2. Jumping ability training on alternate days. Exercises 1, 5, 8 are performed. Number of repetitions for each exercise -20 jumps, 2 series. Pauses between series and exercises 2-3 minutes.

Stage 3. Jumping ability training on alternate days. Exercises 6, 9, 10 are performed. Number of repetitions for each exercise -25 jumps, 3-4 series. Pauses between series and exercises 2-3 minutes.

The subjects in A. Belyayev and L. Bulykina's programme were the male team of Russian super league Odintsovo Iskra. In our study Natasha Sorgina conducted the programme with young volleyballers; therefore, a few changes were made in it.

\section{Catalogue of jumping exercises for the current study}

1. Jumps upwards from half squat with maximum effort (angle between upper and lower leg 130-140 $)$.

2. Jumps onto a gymnastic bench.

3. Step jumps

4. Scissor jumps on the spot

5. Step - squat - jump (step, drop into a deep squat, jump upwards with straight back, arms upwards)

6. Jumps upwards with straight legs forward (with a soft landing)

7. High knee run (at maximum speed, knees high)

8. Jumps over an obstacle (a gymnastic bench) with a turn from deep squat into a deep squat on the other side of the bench (with face always turned to the bench)

9. Imitation of block at the net

10. Jumping with spiking steps with touching a mark above the head

The programme lasted for 54 days for both groups. Thereafter the subjects underwent testing (anthropometric measuring and tests) as at the beginning of the study.

The students of the control group underwent an anthropometric study and test of physical abilities at both times but did not attend jumping ability training meanwhile. 


\section{Statistical analysis of data}

Analysis was performed by Master of Mathematical Statistics Säde Koskel. Primary statistical analysis, linear correlation analysis, t-test to find significant differences between the means of the groups and multivariate regression analysis were applied.

\section{RESULTS}

The analysis began with finding the mean height and weight of the boys and girls of the first and the second group, and the corresponding data of the control group during the first and the second measuring.

Table 1. Mean height and weight of the subjects during the first and the second measuring

\begin{tabular}{|l|c|c|c|}
\hline Group & Variable & $\begin{array}{c}\text { First measuring } \\
\text { (K1) }\end{array}$ & $\begin{array}{c}\text { Second } \\
\text { measuring (K2) }\end{array}$ \\
\hline Group 1 (boys) & Height cm & 185.550 & 185.663 \\
\cline { 2 - 4 } & Weight kg & 71.300 & 71.533 \\
\hline \multirow{2}{*}{ Group 1 (girls) } & Height cm & 167.467 & 167.550 \\
\cline { 2 - 4 } & Weight kg & 61.100 & 60.283 \\
\hline Group 2 (boys) & Height cm & 161.917 & 163.000 \\
\cline { 2 - 4 } & Weight kg & 49.000 & 49.667 \\
\hline Group 2 (girls) & Height cm & 161.250 & 161.625 \\
\cline { 2 - 4 } & Weight kg & 52.000 & 51.250 \\
\hline \multirow{2}{*}{$\begin{array}{l}\text { Group 3 } \\
\text { control) }\end{array}$} & Height cm & 181.625 & 181.625 \\
\cline { 2 - 4 } & Weight $\mathrm{kg}$ & 73.250 & 73.750 \\
\hline
\end{tabular}

The first group included 6 girls and 6 boys aged 16-20 years. The girls' mean height was $167.5 \mathrm{~cm}$ and weight $61.1 \mathrm{~kg}$. The boys' mean height was $185.6 \mathrm{~cm}$ and weight $71.3 \mathrm{~kg}$. The second group consisted of 6 boys and 4 girls aged $8-13$ years. The girls' mean height was $161.3 \mathrm{~cm}$ and weight $52 \mathrm{~kg}$. The boys' mean height was $162 \mathrm{~cm}$ and weight $49 \mathrm{~kg}$. The control group consisted of eight young men aged 17-18 years with a mean height $181.6 \mathrm{~cm}$ and mean weight $73.25 \mathrm{~kg}$.

Table 2 presents the differences between the results of the first and the second series of measurements. 


\begin{tabular}{|c|c|c|c|c|c|c|c|c|c|c|c|c|c|c|c|}
\hline 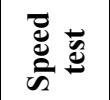 & 6 & $\begin{array}{c}1 \\
\infty \\
a \\
0\end{array}$ & $\frac{a}{m}$ & 6 & $\mid$\begin{tabular}{l}
$m$ \\
$=$ \\
\hdashline \\
1
\end{tabular} & $\mid \begin{array}{l}\infty \\
\stackrel{1}{0} \\
\dot{0}\end{array}$ & 0 & $\left|\begin{array}{c}n \\
n \\
\dot{\varphi}\end{array}\right|$ & 年 & $\nabla$ & 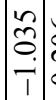 & 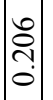 & $\infty$ & $\mid \begin{array}{l}\infty \\
\dot{+} \\
0\end{array}$ & 水 \\
\hline 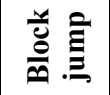 & 0 & $\begin{array}{l}8 \\
8 \\
0 \\
0\end{array}$ & $\mid \begin{array}{c}n \\
\hat{\sigma} \\
-\end{array}$ & 6 & 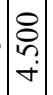 & 梁 & 0 & $\mid \begin{array}{c}8 \\
8 \\
n \\
n \\
\text { n. }\end{array}$ & 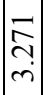 & $\nabla$ & $\mid \begin{array}{ll}0 & 0 \\
& \\
\\
m\end{array}$ & $\mid \begin{array}{c}\infty \\
\\
\\
-1\end{array}$ & $\infty$ & $\mid \begin{array}{l}8 \\
0 \\
n \\
0\end{array}$ & 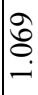 \\
\hline 兰 & 6 & $\begin{array}{c}m \\
m \\
m \\
r\end{array}$ & $\left|\begin{array}{l}n \\
\infty \\
\infty \\
i\end{array}\right|$ & 6 & $\left|\begin{array}{l}m \\
\infty \\
0 \\
0\end{array}\right|$ & $\begin{array}{l}\overline{\hat{\sigma}} \\
\dot{n}\end{array}$ & 0 & $\left|\begin{array}{c}m \\
m \\
m \\
\infty\end{array}\right|$ & 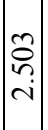 & $\nabla$ & $\begin{array}{lll}8 & 0 \\
0 & 0 \\
\text { rit } & 0\end{array}$ & $\begin{array}{l}\infty \\
\infty \\
\infty \\
\sim\end{array}$ & $\infty$ & in & $\begin{array}{l}2 \\
\infty \\
\end{array}$ \\
\hline 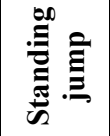 & 6 & $\begin{array}{c}m \\
\infty \\
\infty \\
n \\
\cdots\end{array}$ & 守 & 6 & 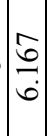 & $\underset{\sim}{\stackrel{N}{\tau}}$ & 6 & $\mid \begin{array}{c}8 \\
8 \\
0 \\
\text { in }\end{array}$ & $\left|\begin{array}{l}2 \\
\stackrel{2}{-}\end{array}\right|$ & $\nabla$ & $\mid \begin{array}{c}8 \\
8 \\
\dot{8} \\
\dot{1}\end{array}$ & 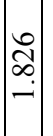 & $\infty$ & $\frac{2}{3}$ & $\begin{array}{l}n \\
m \\
\infty \\
0\end{array}$ \\
\hline 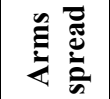 & 6 & 듬 & 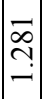 & 6 & $\mid \begin{array}{c}\hat{6} \\
\ddot{0}\end{array}$ & $\left|\begin{array}{l}\infty \\
0 \\
\multirow{+}{0}{} \\
0\end{array}\right|$ & 0 & $\left|\begin{array}{c}m \\
\hat{\infty} \\
- \\
-\end{array}\right|$ & $\left|\begin{array}{c}\stackrel{N}{f} \\
- \\
-\end{array}\right|$ & $\nabla$ & $\stackrel{2}{\simeq}$ & $\begin{array}{l}+ \\
2 \\
\infty \\
0 \\
0\end{array}$ & $\infty$ & $\frac{a}{a}$ & 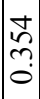 \\
\hline 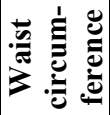 & 0 & \begin{tabular}{c}
$\hat{\sigma}$ \\
\hdashline \\
0 \\
\end{tabular} & $\mid \begin{array}{c}n \\
\bar{\sigma} \\
\text { i }\end{array}$ & 6 & $\left|\begin{array}{c}\hat{0} \\
0 \\
\hdashline \\
\end{array}\right|$ & $\mid \begin{array}{l}\bar{o} \\
\dot{+} \\
\dot{i}\end{array}$ & 6 & 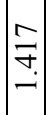 & 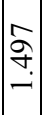 & $\nabla$ & $\mid \begin{array}{l}n \\
n \\
n \\
0\end{array}$ & 용 & $\infty$ & $\begin{array}{l}8 \\
8 \\
0 \\
0\end{array}$ & 尽 \\
\hline 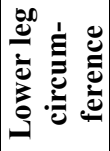 & 6 & $\left|\begin{array}{c}0 \\
\infty \\
0 \\
0 \\
0\end{array}\right|$ & $\mid$\begin{tabular}{c}
\multirow{2}{0}{} \\
స̦ \\
0
\end{tabular} & 6 & $\left|\begin{array}{c}2 \\
\infty \\
0 \\
0\end{array}\right|$ & $\mid \begin{array}{l}0 \\
2 \\
n \\
0\end{array}$ & 6 & $\left|\begin{array}{l}0 \\
0 \\
n \\
0\end{array}\right|$ & 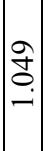 & $\nabla$ & $\mid \begin{array}{l}n \\
n \\
0 \\
0\end{array}$ & $\begin{array}{l}0 \\
0 \\
\vdots \\
0 \\
0\end{array}$ & $\infty$ & $\mid \begin{array}{l}8 \\
0 \\
0 \\
0\end{array}$ & ñ \\
\hline 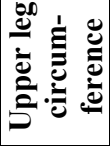 & 6 & \begin{tabular}{c}
$\mathbf{6}$ \\
\hdashline \\
$\dot{0}$
\end{tabular} & $\left|\begin{array}{c}\infty \\
0 \\
\multirow{+}{0}{} \\
0\end{array}\right|$ & 6 & $\left|\begin{array}{c}\hat{6} \\
\hdashline \\
0\end{array}\right|$ & $\left|\begin{array}{l}0 \\
n \\
0 \\
0\end{array}\right|$ & 0 & 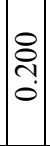 & 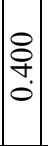 & $\nabla$ & $\mid \begin{array}{l}8 \\
0 \\
n \\
0\end{array}$ & $\begin{array}{l}\infty \\
0 \\
+ \\
0 \\
0\end{array}$ & $\infty$ & $\mid \begin{array}{l}8 \\
8 \\
0 \\
0\end{array}$ & ñ \\
\hline$\frac{5}{200}$ & 0 & $\begin{array}{c}m \\
\hat{n} \\
0 \\
0\end{array}$ & 帒 & 6 & $\mid \begin{array}{l}- \\
\infty \\
0 \\
0\end{array}$ & 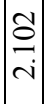 & 6 & $\left|\begin{array}{l}6 \\
0 \\
0 \\
0\end{array}\right|$ & $\mid \begin{array}{c}\hat{2} \\
\hat{\sigma} \\
-\end{array}$ & $\nabla$ & $\mid \begin{array}{l}0 \\
i n \\
\dot{0}\end{array}$ & $\begin{array}{l}\hat{n} \\
\vdots \\
0\end{array}$ & $\infty$ & $\mid \begin{array}{l}8 \\
0 \\
0 \\
0\end{array}$ & . \\
\hline 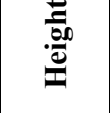 & 6 & $\mid \begin{array}{c}\infty \\
\infty \\
0 \\
0 \\
0\end{array}$ & 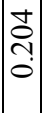 & 6 & $\left|\begin{array}{c}m \\
\infty \\
0 \\
0\end{array}\right|$ & 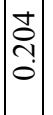 & 0 & $\begin{array}{l}3 \\
\infty \\
0 \\
-1\end{array}$ & 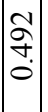 & $\nabla$ & $\begin{array}{c}n \\
m \\
0\end{array}$ & 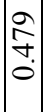 & $\infty$ & $\mid \begin{array}{l}0 \\
8 \\
0 \\
0\end{array}$ & ○ \\
\hline & $\mathbf{Z}$ & 胥 & 氞 & $\mathbf{Z}$ & 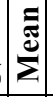 & 包 & $\mathbf{Z}$ & 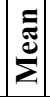 & 产 & $\mathbf{Z}$ & $\underset{\Sigma}{\tilde{\Xi}}$ & 昰 & $\mathbf{Z}$ & $\sum_{\bar{Z}}^{\mathbb{\Xi}}$ & 包 \\
\hline & 司 & & & ڤె & 元 & & 길 & 官 & & 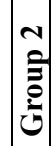 & $\frac{0}{3=}$ & & 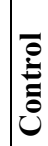 & 음 & \\
\hline
\end{tabular}


The table shows that the results of jumping tests and speed tests improved in all groups. It is also interesting to note that the students were not only influenced by the jumping ability programme, but during these 54 days they also grew. The increase in height was particularly great in the group of younger boys $-1.08 \mathrm{~cm}$ on the average.

One of the aims was to find whether the speed abilities of volleyballers improve if only jumping ability is specially trained.

During those 54 days, we did not do any special exercises to develop the players' speed abilities. Thus, we can conclude that speed abilities and jumping ability are closely related. We found that the time of zigzag run decreased in the group of older boys by $0.98 \mathrm{sec}$ on average, in the group of older girls by $1.11 \mathrm{sec}$, in the group of younger boys by 0.75 $\mathrm{sec}$ and in the group of younger girls by $1.03 \mathrm{sec}$. In the control group where jumping ability was not trained, the time of the zigzag run even increased by $0.15 \mathrm{sec}$.

The improvement in tests results was also proved by t-test.

Table 3. Assessment of physical abilities by t-test

\begin{tabular}{|c|c|c|c|c|}
\hline & Standing jump & Running jump & Block jump & Zigzag run \\
\hline & Test 1 - Test 2 & Test 1 - Test 2 & Test 1 - Test 2 & Test 1 - Test 2 \\
\hline $\begin{array}{l}\text { Group } 1 \\
\text { Boys }\end{array}$ & $286.67-294.50$ & $\begin{array}{c}294.83- \\
302.17\end{array}$ & $280.33-286.33$ & $23.30-24.28$ \\
\hline$(n=6)$ & $(p=0.0001)$ & $(p=0.00077)$ & $(p=0.00016)$ & $(p=0.0003)$ \\
\hline $\begin{array}{l}\text { Group } 1 \\
\text { Girls }\end{array}$ & $248.17-254.33$ & $\begin{array}{c}248.50- \\
255.33 \\
\end{array}$ & $244.17-248.67$ & $26.51-27.62$ \\
\hline$(n=6)$ & $(p=0.0001)$ & $(p=0.00418)$ & $(p=0.0006)$ & $(p=0.000)$ \\
\hline $\begin{array}{l}\text { Group } 2 \\
\text { Boys }\end{array}$ & $245.50-240.50$ & $\begin{array}{c}250.83- \\
242.50 \\
\end{array}$ & $239.50-234.00$ & $27.98-28.73$ \\
\hline$(n=6)$ & $000508)$ & $(p=0.000225)$ & $(p=0.00459336)$ & $\begin{array}{c}(\mathrm{p}=0.1431) \\
\text { Cannot be } \\
\text { statistically } \\
\text { proved }\end{array}$ \\
\hline $\begin{array}{l}\text { Group } 2 \\
\text { Girls }\end{array}$ & $\begin{array}{c}237.75-232 \\
75\end{array}$ & $\begin{array}{c}237.75-234 . \\
25\end{array}$ & $232.75-229.50$ & $31.99-33.025$ \\
\hline$(n=4)$ & $(p=0.00598)$ & $(p=0.04688)$ & $(p=0.00704)$ & $(p=0.001052)$ \\
\hline
\end{tabular}

The table shows that in the first and the second group the results of jumping tests improved significantly in both boys and girls; the time of zigzag run also decreased significantly. The change could not be 
statistically proved only in the zigzag run test of the boys of the second group.

We also compared changes in the jumping and speed abilities in the boys of the first group and the control group.

Table 4. Check-up of essential differences between the means of the boys of the control group and group 1

\begin{tabular}{|l|c|c|c|c|}
\hline & $\begin{array}{c}\text { Standing } \\
\text { jump }\end{array}$ & $\begin{array}{c}\text { Running } \\
\text { jump }\end{array}$ & $\begin{array}{c}\text { Block } \\
\text { jump }\end{array}$ & $\begin{array}{c}\text { Zigzag } \\
\text { run }\end{array}$ \\
\hline Group 1 (boys) & 7.833 & 7.333 & 6.000 & -0.982 \\
\hline $\begin{array}{l}\text { Control group } \\
\text { (boys) }\end{array}$ & 0.125 & 0.250 & 0.500 & 0.148 \\
\hline $\begin{array}{l}\text { Calculated value } \\
\text { of p }\end{array}$ & $\mathrm{P}=0.0000$ & $\mathrm{P}=0.0005$ & $\mathrm{P}=0.0001$ & $\mathrm{P}=0.0002$ \\
\hline
\end{tabular}

Here the results of the boys of the first group improved significantly compared with the boys of the control group who did not attend jumping ability training.

In addition, we also performed correlation analysis of anthropometric data and tests results of all the subjects participating in the study. As repeatedly shown in literature, anthropometric data form a system where all the variables are in mutual statistically significant correlation and the leading variables in this system are height and weight $[3,7]$. We also got the same result when analyzing the anthropometric data of young volleyballers. The anthropometric data were in significant correlation between themselves and also in significant correlation with the results of all tests. Linear regression models proved that, for example, the height of standing vertical jump could be predicted from the number of the group, the child's sex and his/her height when measured for the second time $\left(\mathrm{R}^{2}=0.9529\right)$. An analogous result was received when predicting the height of running vertical jump where the independent variables were also the number of the group, the subject's sex and height when measured for the second time $\left(\mathrm{R}^{2}=0.9562\right)$.

In conclusion, we can say that the jumping ability programme used by us is suitable for young volleyballers, both boys and girls, aged 8-20 years. The authors recommend using the above-mentioned programme as an aid for coaches. 


\section{REFERENCES}

1. Belyayev A. V., Bulykina L. V. (2004). Theory and Practice of Physical Education, 3, 37-38.

2. Häkkinen K. (1989). Maximal force, explosive strength and speed in female volleyball and basketball players. J. Human Movement Studies, 16, 291-303.

3. Kaarma H. (1985). Complex statistical characterization of woman's body measurements. Anthrop. Anz., 53, 239-244.

4. Knussmann R. (1988). Anthropologie. Handbuch der vergleichenden Biologie des Menschen. Band 1: Wesen und Methoden des Anthropologie. Stuttgart, New York: Gustav Fischer, 139-309.

5. Shappard J. M., Dingley A. A., Janssen I., Spratford W., Chapman D. W., Newton R. U. (2011). The effect of assisted jumping on vertical jump height in high-performance volleyball players. Journal of Science and Medicine in Sport, 14, 85-89.

6. Smith D. J., Roberts D., Watson B. (1992). Physical, physiological and performance differences between Canadian national team and universiade volleyball players. Journal of Sport Sciences, 10, 131-138.

7. Stamm R., Stamm M., Koskel S. (2006). Adolescent female volleyballers' (aged 13-15 years) body build classification and proficiency in competitions. Anthropologische Anzeiger, 64 (4), 423-433.

8. Samozino P., Morin J.-B., Hintzy F., Belli A. (2010). Jumping ability: Theoretical integrative approach. Journal of Theoretical Biology, 264, $11-18$.

9. Ziv G., Lidor R. (2010). Vertical jump in female and male volleyball players: a review of observational and experimental studies. Scandinavian Journal of Medicine and Science in Sports, 20, 556-567.

10. Thissen-Milder, Mayhew J. L. (1991). Selection and classification of high school volleyball players from performance tests. J. Sports Med Phys Fitness, 31 (1), 380-384.

11. Viitasalo J. (1988). Evaluation of explosive strength for young and adult athletes. Res. Quar. Exerc. Sports, 59 (1), 9-13.

12. Young W., MacDonald C., Hegger T., Fitzpatrick J. (1997). An evaluation of specificity, validity and reliability of jumping test. J Sports Med Phys Fitness, 37, 240-245.

13. Курамшин Ю. Ф., Першин А. Н., Поповский В. М. (1985). Отбор и прогнозирование потенциальных возможностей волейболистов на этапе начальной подготовки. Институт физической культуры им. П. Ф. Лесгафта. Ленинград, 20 с. 
Address for correspondence:

Meelis Stamm

Educational Science Institute

Tallinn University

Sireli 4, Tallinn 10913, Estonia

E-mail: mella@tlu.ee 